\title{
The allure of the bezoar endures
}

\section{By Omar Fabián}

I found the poor cook on all fours, going like an animal, his tongue out of his mouth, his eyes and his face flaming red ... I made him drink about half a sextier of oil, thinking to save his life; but it was of no service ... he died miserably, crying out he had better have died on the gallows.

Ambroise Paré, Ambroise Paré and His Times, 1510-1590 by Stephen Paget

At the center of that gruesome scene set by Ambroise Paré, a French battlefield surgeon during the Renaissance, was arguably one of history's most controversial materials: the bezoar stone. Once lauded for its magical ability to counteract any poison, the bezoar today is perceived as more of an irritant than a rune - an amalgam of natural substances rather than a supernatural amulet in its own right. But that doesn't mean it's lost all of its luster.

For many people, especially in Asia, bezoars endure as a source of healingso much so that a market for ersatz bezoar powders exists today (a gram's worth can run anywhere from USD\$0.01-100). And despite losing the exalted footing it once held, the bezoar and its curative powers do not appear to be completely discounted by modern science.

Derived from the Persian pād-zahr (literally "antidote"), a bezoar is not truly a stone. It is, in fact, an abnormal mass formed of indigestible material in the gastrointestinal tract of ruminant animals, such as oxen and goats. These masses are typically made of calcium and magnesium layered around plant fiber or a small rock. But any foreign material is potential fodder, whether milk (lactobezoar), feces (fecalith), or hair (tracheobezoar).

First described as medicinal materials by physicians in the Middle Ages, bezoars reached their heyday in the 16th and 17th centuries. It was then that the first theories of how bezoars were formed gained popularity. Among the most favored theories were those offered up by Spanish physician Nicolás Monardes. Citing Arabic sources, Monardes explained that in the summertime, animals that produced bezoars explored cool caves in search of venomous snakes to eat. After their meal, they would seek respite in nearby cold ponds. There, the snakes' "hot" venom would condense into a primordial bezoar.

A variation of that theory - the one preferred by Monardes - held that after bathing, the animals would instinctively munch on magical plants whose healing powers would be infused into the bezoar seed. It was an explanation that seemed to serve the interests of both Monardes and his home country of Spain well. With conquistadors exploring the New World for lucrative commodities, the prospect of finding enchanted flora that gave rise to powerful bezoars meant that a new, Western market for the mystical stones might rival the longestablished Eastern market.

But even back then, skeptics of bezoars' supposed abilities asserted their doubtsmost famously in that opening scene involving Ambroise Paré. He was the surgeon of the French Court, serving under four consecutive kings during the 16th century. When a gentleman appeared before Charles IX and presented him with a Spanish bezoar, Paré was called upon to ascertain its poison-blocking powers. Confident that claims of the stone's abilities were bogus, he made the grim request to test its effects on a "low-risk" subject: a condemned criminal. For the demonstration, King Charles IX chose a cook arrested for stealing two of the court's royal dishes. The cook, Paré recounts, was quite agreeable to his altered sentence, favoring a private death by poison to the public spectacle of the gallows. But as you'll recall from our opening scene, the poor soul would quickly regret his decision.

The golden era of the bezoar would prove rather short-lived. Fast forward less than a hundred years later, and the magimedicinal stock of the bezoar had all but disappeared. Take this caustic entry in the very first edition of the Encyclopaedia Britannica as a sign of the times:

[T]he stone is nothing more than a morbid concretion ... and, notwithstanding its many bloated virtues, it cannot be considered in any other light than as absorbent of the weakest kind. However, [the] bezoar, on account of its high price, if it serves no other purpose, is of an excellent use in the apothecaries bill.

Ouch.

But don't be too quick to judge, as the allure of the bezoar endures.

A quick search for "calculus bovis" (ostensibly ox bezoars or gallstones) reveals that the bezoar is still bought, sold, and even produced artificially today. Billed as a feverreducing anti-inflammatory, the bezoar is a common ingredient in Chinese medicine. And of the bezoar's ability to ward off the effects of poison, there are reports of experiments dating from as late as the 20th century that offer proof of principle.

Demonstrations by GustafArrhenius and Andrew A. Benson of the Scripps Institution of Oceanography, for example, purportedly showed that bezoar stones could absorb arsenic through ion exchange - the phosphate in the stones being substituted by arsenate in solution.

But of peer-reviewed research, there is little to speak.

For all of his misplaced intentions and expectations, and those of his successors, Nicolás Monardes offered up a few words of wisdom on the medicinal power of natural materials, such as the bezoar, that perhaps best capture how the distinction between science and pseudoscience is truly a fine line:

It is our fault not to investigate them, not to look for them, not to be as diligent as we should be in order to profit from their marvelous effects. And I hope that time, which is the discoverer of all things, and diligence and experience will demonstrate them to us. 